ZBIGNIEW ZIOLO

Akademiı Pedagogiczna, Krakỏw

\title{
Problemy integracji międzynarodowej przemysłu w procesie zmian systemu gospodarowania
}

Problemy transformacji struktur przemysłowych w Polsce i krajach Europy Środkowej dokonujące się w procesie przechodzenia do gospodarki rynkowej są niezwykle aktualne i wymagają ciągłych badań empirycznych oraz wypracowywania coraz doskonalszych syntetyzujących ujęć teoretycznych i modelowych. Ciągle więc aktualna jest potrzeba śledzenia procesów transformacji dla wypracowywania coraz lepszych koncepcji strategicznych zarówno u skali przedsiębiorstw jako układów mikroekonomicznych, jak i mezoekonomicznych układów organizacyjno-kapitałowych tworzących różnej skali terytorialne formy koncentracji przemysłu (skupienia przemysłowe, zespoły, ośrodki, okręgi czy kompleksy przemysłowe) a także układów makroekonomicznych państwa czy układów globalnych. Równocześnie należy przyjąć, iż zaznaczające się przemiany w środkowej części Europy dokonują się w powiązaniu z globalnymi procesami rozwoju cywilizacyjnego (Gorzelak, Jałowiecki, Ḱukliński, Zienkiewicz 1995; Zioło 1997).

Wobec doskonalenia technik łączności i środków transportu odległość fizyczna dla wspólcześnie rozwijających się firm odgrywać będzie coraz mniejszą rolę. W procesie funkcjonowania układów przemysłowych rosnąć będzie natomiast znaczenie globalnych powiązań organizacyjno-kapitalowych. Nawiązywać one będą do coraz bardziej postępującego procesu koncentracji kapitału, instytucji finansowych (głównie banków), jak i różnego typu firm. Wskazują na to współcześnie powstające i rozwijające się powiązania polskich przedsiębiorstw przemysłowych z kapitałem zagranicznym.

Powiązania firm polskich $\mathrm{z}$ firmami zagranicznymi wynikają z coraz silniej zaznaczających się procesów globalizacji, prowadzących do coraz ściślejszej integracji produkcyjnej, marketingowej, naukowo-badawczej, kapitałowej itp. Odnosi się to nie tylko do wytwarzania nowoczesnych produktów, wymagających zaangażowania dużych środków finansowych na badania naukowe w skali podstawowej, laboratoryjnej, półtechnicznej, a później uruchomienia produkcji w skali technicznej czy masowej, ale także do prowadzenia działalności marketingowej i nakładów na reklamę.

Wprawdzie nadal aktualne jest hasło Schumachera (1981) „małe jest piękne", ale w gospodarce państw wysoko rozwiniętych od ponad 30 lat trwa intensywny proces koncentracji organizacyjno-produkcyjnej i finansowej przedsiębiorstw, w którym przyjmuje się, 
że „duże jest lepsze”. Ten nowocześnie pomyślany proces koncentracji organizacyjno-finansowej zapoczątkowany został w polowie lat 70. w USA, a w latach 80 . objął także Europę Zachodnią.

W układzie światowym występują trzy główne strefy koncentracji największych przedsiębiorstw (przemysłowych, handlowych, energetycznych): Stany Zjednoczone, Japonia i Unia Europejska (tab. 1). Spośród 500 największych w świecie przedsiębiorstw najwięcej, bo aź 164 jednostek, czyli 32\%, występuje na terenie Stanów Zjednoczonych, w Europie Zachodniej - 25\%, a w Japonii - 22\%. Cztery główne strefy geograficzne odznaczają się zróżnicowanym udziałem potencjału ekonomicznego wiodących przedsiębiorstw (tab. 2). Obroty iv dwudziestu największych firmach japońskich osiągają 1316,2 mld dol., podczas gdy w dwudziestu największych firmach Stanów Zjednoczonych wynoszą one 993,5 mld dol., a w dwudziestu największych firmach Europy Zachodniej - 807,8 mld dol. Na pozostałym obszarze w dwudziestu dominujących firmach obroty wynoszą tylko 356,4 mld dol. Łączne obroty na terenie wyróżnionych stref w ich dwudziestu największych firmach wynoszą 3473,9 mld dol.

Tabela I. Koncentracja przestrzenna 500 największych przedsiębiorstw przemysłowych w $1990 \mathrm{r}$.

\begin{tabular}{|l|c|c|}
\hline \multicolumn{1}{|c|}{ Obszar } & Liczba przedsiębiorstw & Procentowy udzial \\
\hline Stany Zjednoczone & 164 & 32,8 \\
\hline Europa Zachodnia & 129 & 25,8 \\
\hline Japonia & 111 & 22,2 \\
\hline Inne kraje europejskie & 42 & 8,4 \\
\hline Inne kraje & 54 & 10,8 \\
\hline Ogólem & 500 & 100,0 \\
\hline
\end{tabular}

Źródło: A. Vincent, J.P. Martens (1996)

Tabela 2. Obroty i zatrudnienie w 20 największych przedsiębiorstwach w czterech strefach geograficznych świata

\begin{tabular}{|l|c|c|c|c|c|}
\hline \multicolumn{1}{|c|}{ Obszar } & $\begin{array}{c}\text { Obroty } \\
\text { w mld } \\
\text { dol. USD }\end{array}$ & $\begin{array}{c}\text { Liczba } \\
\text { zatrudnionych } \\
\text { w tys. }\end{array}$ & $\begin{array}{c}\text { Udziat } \\
\text { w obrotach }\end{array}$ & $\begin{array}{c}\text { Udzial } \\
\text { w zatrudnieniu }\end{array}$ & $\begin{array}{c}\text { Obroty } \\
\text { na zatrudnionego } \\
\text { w tys. dol }\end{array}$ \\
\hline Stany Zjednoczone & 993,5 & 4460 & 28,6 & 37,6 & 222,8 \\
\hline Europa Zachodnia & 807,8 & 4122 & 23,3 & 34,8 & 196,0 \\
\hline Japonia & 1316,2 & 1515 & 37,9 & 12,8 & 868,8 \\
\hline Inne & 356,4 & 1750 & 10,3 & 14,8 & 203,7 \\
\hline Ogółem & 3473,9 & 11847 & 100,0 & 100,0 & 293,2 \\
\hline
\end{tabular}

Źródlo: A Vincent, J.P. Martens (1996)

W skali światowej dominujące znaczenie w obrotach tej kategorii przedsiębiorstw mają firmy japońskie, których udział w ogólnych obrotach wynosi 37,9\%, podczas gdy skupiają one tylko 12,8\% ogólnego zatrudnienia. Firmy Stanów Zjednoczonych obejmują 28,6\% obrotów i 37,6\% zatrudnionych, a firmy Europy Zachodniej w ogólnych obrotach obejmują $23,3 \%$, a w zatrudnieniu - 34,8\%. Biorąc pod uwage obroty na jednego zatrudnionego zdecydowaną przewagę mają firmy japońskie, dla których wskaźnik ten wynosi aż 
868,8, podczas gdy w firmach Stanów Zjednoczonych - 222,8, a w Europie Zachodniej 196,0. Podkreśla to bardzo zróżnicowaną wydajność pracy, która w zasadniczym stopniu wpływa na pozycję konkurencyjności tych firm.

Wśród 54 wiodących w świecie przedsiębiorstw przemysłowych (których obroty wynoszą ponad $20 \mathrm{mld}$ dol.) zdecydowaną przewagę ma amerykańska firma General Motors, której obroty w 1990 r. wynosiły 125,1 mld dol., tj. 5,7\% łącznych obrotów tej kategorii firm (tab. 3). Kolejną pozycję zajmuje Roval/Shell - holendersko-angielskie przedsiębiorstwo, którego obroty stanowią 4,9\% oraz amerykańska firma Exxon obejmująca 4,8\% obrotów tej kategorii przedsiębiorstw. W tej grupie przedsiębiorstw zdecydowaną przewagę mają przedsiębiorstwa Stanów Zjednoczonych. Obroty 16 firm tej grupy obejmują 33,1\% ich ogólnych obrotów, a tylko 26,6\% zatrudnionych (tab. 4). Kolejną pozycję zajmują firmy japońskie, których udział w obrotach wynosi $21,4 \%$, a w zatrudnieniu $-22,2 \%$. Trzecią pozycję zajmują przedsiębiorstwa niemieckie, a następnie brytyjskie i francuskie. Zdecydowanie mniejsze znaczenie mają pozostałe kraje (Korea i Wenezuela). Przedstawione rozważania wskazują na silną koncentrację wiodących przedsiębiorstw przemysłowych w trzech wspomnianych strefach: Stanach Zjednoczonych, Japonii i Europy Zachodniej.

O żnaczącej roli w gospodarce światowej Stanów Zjednoczonych, Japonii i Europy Zachodniej oraz ich dystansie cywilizacyjnym w stosunku do pozostałych obszarów świadczą obroty 30 wiodących w świecie firm komputerowych. Udział Stanów Zjednoczonych i Kanady w tych obrotach wynosi 57,9\%, Japonii - 27,0\%, łącznie na kraje Europy Zachodniej przypada tylko 14,6\%, podczas gdy na resztę świata zaledwie 0,5\% (Howells, Wood 1991 ).

Dla rozwoju największych przedsiębiorstw podstawowe znaczenie mają tzw. rynki pierwsze, które są głównym odbiorcą ich produktów (tab. 5). Pierwszymi rynkami dla największych firm są kraje, na terenie których się one wykształciły. Dla firm Stanów Zjednoczonych pierwszym rynkiem są one same, a następnie Europa Zachodnia. Na terenie Stanów Zjednoczonych dominującą część swojej produkcji zbywa np. firma Ford - ok. 71\%, General Motors - 69\% i IBM - 63\%. Natomiast na terenie Europy Zachodniej firmy te zbywają odpowiednio: $19 \%$, 28\% i 35\%.

Tabela 3 Wiodące światowe przedsiębiorstwa przemysłowe w $1990 \mathrm{r}$.

\begin{tabular}{|c|c|c|c|c|}
\hline Nazuy firmy & Kraj & $\begin{array}{c}\text { Obroty } \\
\text { w mld dol. USD }\end{array}$ & $\begin{array}{c}\text { Liczba } \\
\text { zatrudnionych }\end{array}$ & $\begin{array}{l}\text { Obroty na zatrudnio- } \\
\text { nego w tys. dol. USD }\end{array}$ \\
\hline 1 & 2 & 3 & 4 & 5 \\
\hline General Motors & USA & 125,1 & 761,4 & 164,3 \\
\hline Roval/Shell & Holandia/W. Brytania & 107,2 & 137,0 & 782,5 \\
\hline Exxon & USA & 105,9 & 104,0 & 1018.3 \\
\hline Ford & USA & 98,3 & 370,4 & 265,4 \\
\hline IBM & USA & 69,0 & 373,8 & 184,6 \\
\hline Toyota & Japonia & 64,5 & 96,8 & 666,3 \\
\hline IRI & Włochy & 61,4 & 419.5 & 146.4 \\
\hline$B P$ & W. Brytania & 59,5 & 116.7 & 509.9 \\
\hline Mobil & USA & 58,8 & 67,3 & 873.7 \\
\hline General Electric & USA & 58,4 & 298,0 & 196.0 \\
\hline Daimler-13enz & Niemcy & 54,3 & 376,8 & 144.1 \\
\hline Hitachi & Japonia & 50.7 & 290,8 & 174.3 \\
\hline
\end{tabular}




\begin{tabular}{|c|c|c|c|c|}
\hline 1 & 2 & 3 & 4 & 5 \\
\hline Fiat & Wlochy & 47,7 & 303,2 & 157,3 \\
\hline Samsung & Korea & 45,0 & - & - \\
\hline Philip Morris & USA & 44,3 & 168,0 & 263,7 \\
\hline Volkswagen & Niemcy & 43,7 & 268,7 & 162,6 \\
\hline \begin{tabular}{|l|} 
Matsushila Electric \\
\end{tabular} & Japonia & 43,5 & 198,3 & 219,4 \\
\hline ENI & Włochy & 41,8 & 130,7 & 319,8 \\
\hline Texaco & USA & 41,2 & 39,2 & 1051,0 \\
\hline Nissan Motor & Japonia & 40,2 & 129,5 & 310,4 \\
\hline Unilever & Holandia/W. Brytania & 40,0 & 304,0 & 131,6 \\
\hline Chevron & USA & 39,3 & 54,2 & 725,1 \\
\hline Siemens & Niemcy & 39,2 & 373,0 & 105,1 \\
\hline At\&T & USA & 37,5 & 273,7 & 137,0 \\
\hline Nestle & Szwajcaria & 33,3 & 199,0 & 167,3 \\
\hline Elf Aquitaine & Francja & 32,9 & 90,0 & 365,6 \\
\hline Chrysler & USA & 30,9 & 124,0 & 249,2 \\
\hline Philips & Holandia & 30,9 & 272,8 & 113,3 \\
\hline Toshiba & Japonia & 30,2 & 142,0 & 212,7 \\
\hline Renault & Francja & 30,1 & 157,4 & 191,2 \\
\hline \begin{tabular}{|l|} 
Peugeot \\
\end{tabular} & Francja & 39,4 & 159,1 & 247,6 \\
\hline BASF & Niemcy & 29,2 & 134,6 & 216,9 \\
\hline Amoco & USA & 28,3 & 54,5 & 519,3 \\
\hline Hoechst & Niemcy & 27,7 & 172,9 & 160,2 \\
\hline Asea Brown Boveri & Finlandia/Szwajcaria & 27,7 & 212,2 & 130,5 \\
\hline Boeing & USA & 27,6 & 161,7 & 170,1 \\
\hline Honda & Japonia & 27,1 & 79,2 & 342,2 \\
\hline Alcatel Alsthom & Francja & 26,5 & 205,5 & 129,0 \\
\hline Bayer & Niemcy & 26,1 & 171,0 & 152,6 \\
\hline NEC & Japonia & 24,4 & 114,6 & 212,9 \\
\hline Procter \&Gamble & USA & 24,4 & 88,8 & 274,8 \\
\hline \begin{tabular}{|l|} 
Total \\
\end{tabular} & Francja & 23,6 & 55,0 & 429.1 \\
\hline Petroleos de Venezu & Wenezuela & 23,5 & 51,9 & 452,8 \\
\hline $\mathrm{ICI}$ & W. Brytania & 23,3 & 132,1 & 176,4 \\
\hline Daewoo & Korea & 22,3 & 85,8 & 259,9 \\
\hline Occidental Petroleum & USA & 21,9 & 55,4 & 395,3 \\
\hline RWE & Niemcy & 21,8 & 97,6 & 223,4 \\
\hline United Technologies & USA & 21,8 & 192,6 & 113,2 \\
\hline Thyssen & Niemcy & 21,5 & 152,1 & 141.4 \\
\hline Mitsubischi Electric & Japonia & 21,2 & 89,1 & 237.9 \\
\hline Nippon Steel & Japonia & 21,2 & 72,9 & 290,8 \\
\hline Sony & Japonia & 20,9 & 95,6 & 218,6 \\
\hline Petrobras & W. Brytania & 20,2 & & \\
\hline Dow Chemical & USA & 20,0 & 62,1 & 322.1 \\
\hline Ogólem & & 2196,4 & 9336,5 & 235,2 \\
\hline
\end{tabular}

Źrỏdlo: „Fortune”, 29 lipca i 26 sierpnia 1991, za: A. Vincent, J.P. Martens (1996) 
Tabela + Lokalizacja zarządów wiodących światowych przedsiębiorstw przemysłowych w $1990 \mathrm{r}$.

(o obrotach ponad $20 \mathrm{mld}$ dolarów USD)

\begin{tabular}{|l|c|c|c|c|c|}
\hline \multicolumn{1}{|c|}{ Kraj } & $\begin{array}{c}\text { Liczba } \\
\text { przedsiębiorstw }\end{array}$ & $\begin{array}{c}\text { Obroty } \\
\text { w mld dol. } \\
\text { USD }\end{array}$ & $\begin{array}{c}\text { Liczba } \\
\text { zatrudnionych }\end{array}$ & $\begin{array}{c}\text { Udzial } \\
\text { w obrotach }\end{array}$ & $\begin{array}{c}\text { Udział } \\
\text { w zatrudnieniu }\end{array}$ \\
\hline USA & 16 & 727,6 & 2487,7 & 33,1 & 26,6 \\
\hline Japonia & 11 & 469,0 & 2070,2 & 21,4 & 22,2 \\
\hline Niemcy & 8 & 263,5 & 1746,7 & 12,0 & 18,7 \\
\hline Francja & 5 & 152,5 & 667 & 6,9 & 7,1 \\
\hline Włochy & 3 & 150,9 & 853,4 & 6,9 & 9,1 \\
\hline $\begin{array}{l}\text { Holandia/ } \\
\text { W.Brytania }\end{array}$ & 2 & 147,2 & 441 & 6,7 & 4,7 \\
\hline W. Brytania & 3 & 103,0 & 248,8 & 4,7 & 2,7 \\
\hline Korea & 2 & 67,3 & 85,8 & 3,1 & 0,9 \\
\hline Szwajcaria & 1 & 33,3 & 199 & 1,5 & 2,1 \\
\hline Holandia & 1 & 30,9 & 272,8 & 1,4 & 2,9 \\
\hline Finlandia/ & 1 & 27,7 & 212,2 & 1,3 & 2,3 \\
Szwajcaria & & 23,5 & 51,9 & 1,1 & 0,6 \\
\hline Wenezuela & 1 & 2196,4 & 9336,5 & 100,0 & 100,0 \\
\hline Ogółem & 54 & & & & \\
\hline
\end{tabular}

Żródlo. ,Fortune”. 29 lipca i 26 sierpnia 1991, za: A. Vincent. J.P. Martens (1996)

Tabela 5. Rynki pierwotne i wtórne wybranych przedsiębiorstw

\begin{tabular}{|l|c|c|c|}
\hline \multirow{2}{*}{ Kraje/Przedsiębiorstwa } & \multicolumn{3}{|c|}{ Udział w rynku w procentach } \\
\cline { 2 - 3 } & Japonia & USA & Europa \\
\hline Japonia & & & \\
\hline Mitsui & 64 & & \multirow{2}{*}{ ok. 10} \\
\hline Marubeni & 77 & & \\
\hline Mitsubishi & 82 & & \\
\hline USA & & & 35 \\
\hline IBM & & 63 & 19 \\
\hline General Motors & & 69 & 28 \\
\hline Ford & & 71 & \\
\hline Exxon & & 23 & \\
\hline Europa Zachodnia & & & 68 \\
\hline BP & & & 67 \\
\hline Daimler-Benz & & & 78 \\
\hline Volkswagen & & & 58 \\
\hline Royal Dutch/Shell & & & \\
\hline Fiat & & & 91 \\
\hline
\end{tabular}

Źródło: A. Vincent, J.P. Martens (1996) 
Podobnie rynkiem pierwszym dla firm japońskich jest Japonia, na terenie której np. Mitsubishi zbywa $82 \%$ swojej produkcji, a Mitsui $64 \%$, podczas gdy na terenie Europy zbywają one ok. $10 \%$ produkcji. Również dla największych firm Europy Zachodniej najważniejsze są rynki Unii Europejskiej, które wchłaniają podstawową część produkcji. Np. firma Fiat $91 \%$ swojej produkcji zbywa na terenie Europy Zachodniej, przy czym głównie we Włoszech (ok. $51 \%$ ), podobnie Volkswagen $-78 \%$, czy firma $\mathrm{BP}-68 \%$. Podstawową rolę odgrywają głównie rynki narodowe, które wchłaniają ok. $40 \%$ produkcji poszczególnych firm.

Europa Zachodnia wkroczyła w lata 90. ze znaczną liczbą wielkich i silnych przedsiębiorstw, które w zasadniczym stopniu wpływały na rozwój gospodarczy tego kontynentu. W 1990 r. na terenie EWG funkcjonowało około $14 \mathrm{mln}$ przedsiębiorstw zatrudniających około $92 \mathrm{mln}$ pracowników, a ich wyroby miały wartość około 10,5 bil. ECU (Vincent, Martens 1996). W stosunku do 1988 r. nastapil wzrost liczby przedsiębiorstw o ok. 8\%, a obrotów o ok. 13\%, przy spadku zatrudnienia o ok. $8 \%$. Podkreśla to fakt, iż duża dynamika wartości produkcji dokonywała się poprzez rosnącą jej automatyzację, przy znacznym spadku zatrudnienia. W strukturze rodzajowej przedsiębiorstw dominujące znaczenie miały przedsiębiorstwa handlowe obejmujące około $43 \%$ firm, pozostałe to firmy usługowe (32\%), budowlane (13\%) i przemysłowe (12\%).

W strukturze wielkościowej przedsiębiorstw występują duże dysproporcje. Pod względem liczebności dominowały bardzo małe przedsiębiorstwa, które stanowiły $93 \%$ ogólnej ilości i zatrudniały $32 \%$ pracowników, podczas gdy zaledwie 12 tys. dużych firm $(0,001 \%)$ zatrudniało $28 \%$ pracowników.

W największych 150 firmach znajdowało zatrudnienie $12 \mathrm{mln}$ pracowników, przy przeciętnym zatrudnieniu ok. 78 tys. osób. Firmy te:

- nywierały istotny wpływ na dochód narodowy krajów (np. w Wielkiej Brytanii ok. $38 \%$ produktu narodowego brutto, w Niemczech - ok. $42 \%$, a w Holandii - ok. 57\%),

miały one charakter ponadnarodowy, obejmowały rynek europejski i pozaeuropejski.

- składały się z kilkunastu do kilkuset spólek o różnych typach powiązań wewnętrznych,

- charakteryzowały się różną strukturą własnościową (publiczne, prywatne, spółdzielcze lub ich kombinacje).

W konsekwencji grupy bardzo dużych firm okazały się uprzywilejowaną formą organizacji i koncentracji władzy gospodarczej i coraz silniej wpisują się w struktury władzy. Szczególne znaczenie tych grup przejawia się $w$ dynamizacji procesu integracji europejskiej. Mają one i mieć będą nadal coraz większe znaczenie w ekspansji Unii Europejskiej na kraje Europy Środkowej. Podstawowym atutem tych firm jest dysponowanie dużym kapitałem, sprawną organizacją, dużym doświadczeniem we współpracy międzynarodowej. Stąd przedsiębiorstwa te są w stanie w istotny sposób wpływać na przekształcenia dokonujące się w gospodarce poszczególnych krajów.

Rozszerzanie rynków zbytu wielkich firm na tereny innych krajów dokonuje się głównie poprzez działania marketingowe, wznoszenie nowych inwestycji i przenoszenie produkcji na nowe miejsca. W nowym miejscu inwestycje te pobudzaja procesy restrukturyzacji isıniejących firm, aktywizują lokalne czy krajowe zasoby pracy, energii, surowców, przyśpieszajį wkraczanie nowych technologii produkcji, nowych organizacji oraz wzorców zachowań. Wpływają w ten sposób na integrowanie działalności innych firm i gospodarek, włączając je np. w obręb nowych sieci rynków zbytu. Wszystkie te zmiany i działania do- 
konujące się w strukturze wielkiego przedsiębiorstwa (ponadnarodowej firmy) mają na celu podnoszenie konkurencyjności własnej produkcji i w konsekwencji zwiększenie zysków, niekiedy nawet $w$ dalszym okresie czasu.

Działalność wielkich ponadnarodowych firm w miejscach lokalizacji ich filii uruchamia proces konkurencji z firmami dotychczas funkcjonującymi na danym obszarze. Prowadzi to często do negatywnych skutków dla gospodarki. Istniejące na danym obszarze firmy oraz instytucje bankowe danego obszaru nie mają często własnych środków kapitałowych dla sprostania konkurencji, co w konsekwencji prowadzi je do bankructwa.

Podstawowym celem wielkich firm jest stałe podnoszenie własnej pozycji poprzez wprowadzanie coraz to nowych i tańszych produktów na rynek.

W strukturze przestrzenno-produkcyjnej dużych firm umownie można wyróżnić dwa uklady: centralny i peryferyjny.

Uklad centralny i charakteryzuje się:

- skupieniem na jego obszarze podstawowych badań naukowych związanych z doskonaleniem istniejących produktów i podejmowaniem prac nad produktami nowymi,

- prowadzeniem badań laboratoryjnych,

- uruchamianiem produkcji w skali półtechnicznej,

- podejmowaniem produkcji w skali technicznej i opanowywaniem produkcji masowej.

Na teren układu peryferyjnego przenoszona jest zwykle produkcja masowa (seryjna) opanowana wcześniej w strefie centralnej. Przenoszenie produkcji masowej na ten układ dokonuje się w wyniku „wypychania” jej ze strefy centralnej przez nowocześniejsze asortymenty wdrażane do produkcji, które wymagają odpowiednich urządzeń $\mathrm{i}$ powierzchni produkcyjnej. Strefa peryferyjna przejmuje więc na swój teren produkcję, która ustępuje pod względem nowoczesności produkcji wdrażanej w układzie centralnym. Natomiast zbyt produkçi masowej jest podstawowym czynnikiem zasilania finansowego układu centralnego. Układ peryferyjny obejmuje stosunkowo uboższe obszary. Często towarzyszy temu przenoszenie sprawnego technicznie, ale zużytego moralnie parku maszynowego na dany obszar, który jednak w stosunku do miejscowego parku maszynowego jest uważany za nowoczesny. W rozprzestrzenianiu się firmy ponadnarodowej, zwykle poprzez wkraczanie obcego kapitału na obszar stojący na niższym poziomie rozwoju gospodarczego, jej ośrodki decyzyjne przekazują starsze technologie, a w związku z tym i produkty, natomiast technologie i produkty najnowsze pozostawiane są w miejscowych zakładach. Proces ten występuje nie tylko na terenie Europy, ale mozna przyjąć, że ma charakter światowy (Czerny 1994).

Na obszar peryferyjny wkracza różny typ kapitału. Generalnie możemy wyróżnić niewielki kapitał spekulacyjny i kapitał duży. Kapitał spekulacyjny szuka zwykle szybkiego zysku, stąd odznacza się stosunkowo małą stabilnością przestrzenną i wykazuje silne tendencje do migracji. Duży kapitał jest bardziej stabilny i poszukuje nowych miejsc swojej produkcji, biorąc pod uwagę: niskie koszty pracy, system ulg, mniej rygorystyczne wymogi ekologiczne $\mathrm{i}$ in. Ewentualny zysk odkładany jest na dalsze lata, a ważne znaczenie ma dla niego zajęcie dogodnej pozycji strategicznej na przyszłość.

Relacje między układem centralnym a peryferyjnym są zmienne i przybierają różne formy. Wstępnie można wyróżnić cztery formy powiązań, które w miarę pogłębiania studiów będą uzupełniane i rozwijane. 
Najprostszą formą relacji są powiązania w zakresie wykorzystania zasobów pracy. Układ centralny, dysponujący zasobami kapitałowymi, nowoczesnymi strukturami organizacyjno-logistycznymi, technologia, przesyła własne półfabrykaty i surowce na teren peryferyjny, gdzie dokonuje się zwykle montaż wyrobów gotowych. Następnie cała produkcja przesyłana jest na rynki układu centralnego, a wygenerowane zyski zasilają kapitały firmy. Atrakcyjność układu peryferyjnego wiąże się głównie z względnie niższymi kosztami pracy. Na jego obszarze dochodzi do aktywizacji siły roboczej (obniżania stopnia bezrobocia), wykorzystywania infrastruktury, tańszej energii i często niewykorzystanych powierzchni produkcyjnych. Nadto działalność ta zwiększa dochody gospodarstw pracowniczych oraz w formie podatków zasila budżety struktur samorządowych. Płynące stąd dochody finansowe są nowym czynnikiem pobudzającym wzrost gospodarczy tego układu.

Bardziej złożoną formą relacji między układem centralnym firmy a jej układem peryferyjnym jest zwiększenie udziału peryferiów w produkcji finalnej oraz w zakresie rozszerzania rynku zbytu własnych produktów. Układ centralny reprezentuje tu również kapitał, struktury organizacyjno-logistyczne, technologie, natomiast układ peryferyjny wzbogacony jest o dostawy surowcowe oraz powiązania kooperacyjne w zakresie dostarczania półproduktów do produkcji finalnej. Formę tę wzbogacają również nowe rynki obejmujące obszar układu peryferyjnego. Podstawowymi przesłankami tworzenia takiej formy działalności, obok tanich zasobów pracy, mogą być nadto: unikalne lub tańsze surowce, niższe wymogi ekologiczne czy niższe koszty działalności kooperacyjnej. Dodatkowym elementem tej formy jest transfer zysku do ukladu centralnego.

Najbardziej złożoną formą jest przeniesienie na teren układu peryferyjnego części struktur kapitałowych i technologicznych oraz przeniesienie wyspecjalizowanej produkcji asortymentowej, a także pozyskanie nowych rynków poza układem centralnym i układem peryferyjnym. Jest to wstępna faza rozszerzania struktur układu centralnego poprzez włączenie do niego układu peryferyjnego.

Kolejną formą jest ukształtowanie się nowego układu centralnego poprzez podział firmy i usamodzielnienie się byłego układu peryferyjnego. Proces ten dokonuje się w drodze systematycznego podnoszenia konkurencyjności danego układu peryferyjnego w stosunku do innych tego typu układów (Zioło 1999). Problematyka te wymaga jednak dalszego poznania na tle rozwijającego się procesu globalizacji, w którym coraz poważniejszą rolę będą odgrywać wiodące firmy ponadnarodowe.

Rozprzestrzenianie się układów centralnych opiera się na regułach konkurencyjności produkcji oraz na konkurencyjności miejsc lokalizacji (Kuciński 1993). Proces ten niesie ze sobą także negatywne skutki dla danych układów przestrzennych. Przejawiają się one niszczeniem istniejących i potencjalnie konkurencyjnych przedsiębiorstw, spekulacją środkami produkcyjnymi innych firm poprzez ich wcześniejszy preferencyjny zakup, a także nielegalnym wyprowadzaniem zysków firmy.

W swietle przedstawionych rozważań należy przyjać, iż w mechanizm procesu globalnego rozwoju coraz bardziej włączane będą także firmy państw Europy Środkowej. Poprzez odpowiednie działania dostosowawcze muszą one systematycznie podnosić swoją konkurencyjność i w racjonalny sposób włączać się w struktury firm ponadnarodowych. Przejawem tego jest znaczny spadek wartości produkcji oraz zamiana orientacji powiązań kooperacyjnych w zakresie zbytu wyrobów (tab. 6). Pod koniec okresu centralnego sterowania 
badane przedsiębiorstwo położone na terenie Polski poludniowo-wschodniej wykazywało najsilniejsze powiązania z byłym ZSRR, kierując na jego teren $63,4 \%$ ogólnej wartości zbytu, a następnie z Kanada $(11,2 \%)$ i Indiami. W latach wdrażania reguł gospodarki rynkowej w 1996 r. udział byłego ZSRR zmniejszył się do 1,0\%. Dominująca pozycję w tym zakresie przejęły Niemcy, których udział w tym czasie zwiększył się z 3,9\% do 29,2\%. Nowym odbiorcą produktów stały się Stany Zjednoczone, przyjmujące 16,1\% wartości zbytu. Znacznie zwiększył się udział dostaw kierowanych do Kanady - z 11,2\% do 19,3\%. Upadły powiązania z byłą Czechosłowacją - z 3,3\% do 0,5\%.

Tabela 6. Zmiana powiązań kooperacyjnych przedsiębiorstwa w latach 1989-1996

\begin{tabular}{|c|c|c|}
\hline Kraj & 1989 & 1996 \\
\hline Ogółem & 100,0 & 100,0 \\
\hline w tym: & & \\
\hline ZSRR & \multirow[t]{2}{*}{63,5} & 0,0 \\
\hline Ukraina & & 1,0 \\
\hline Kanada & 11,2 & 19,3 \\
\hline Indie & 5,5 & 2,9 \\
\hline NRD & 3,1 & \multirow[t]{2}{*}{29,2} \\
\hline NRF & 0,8 & \\
\hline USA & 0,0 & 16,4 \\
\hline Słowacja & \multirow[t]{2}{*}{3,3} & 0,5 \\
\hline Czechosłowacja & & 0,0 \\
\hline
\end{tabular}

Żródło: Dane badanego przedsiębiorstwa

\section{Literatura}

Czerny M.. 1994, Restrukturyzacja przemystu i rozwój regionalny Meksyku. Studia i materiaty. Uniwersytet Warszawski. Centrum Studiów Latynoamerykańskich. Warszawa.

Gorzelak G., Jalowiecki B., Kukliński A., Zienkiewicz L., 1995, Europa Środkowa 2005, perspektywy rozwoju, Komitet Prognoz .Polska w XXI wieku” PAN, Europejski Instytut Rozwoju Regionalnego i Uniwersytet Warszawski, Warszawa.

Hingel A.J.. 1993. Note on "A New Model of European Development", Commission of the European Communities, FOP 36I-EN, September.

Howells I., Wood M., 1991. The Globalisation of Production and Technology Commission of the European Communities, Monitor, FOP 274.

Kuciński K.. 1993. Aglomeracja miejska jako środowisko lokalizacji firmy. SGH, Wydzial Ekonomiki Produkcji. Warszawa.

Schumacher E.F., 1981, Mate jest piękne: spojrzenie na gospodarkę świata z zatozeniem, ze czlowiek coś znaczy. PIW, Warszawa.

Vincent A.. Martens J.P., 1996, Ugrupowanie gospodarcze, Poltext. Warszawa.

Ziolo Z., 1997, Uwarunkowania rozwoju spoteczno-gospodarczego państw Europy Środkowej, [w:] Procesy integracji systemowej w jednoczqcej się Europie, red. J. Jabłoński, W. Maik, Przegląd Regionalny, nr 2, Toruń.

Zioło Z., 1999, .Konkurencyjność miast w ukladach przestrzennych“. Oddano do druku w Wyd. Nauk. AE, Kraków. 